\title{
Advanced endoscopic imaging of colonic schistosomiasis
}

A 21-year-old patient was referred to our unit with a 3-month history of abdominal discomfort, bloating, and intermittent diarrhea. Physical findings were normal; however, eosinophilia (4300/ $\mathrm{LL}$; 35\%) was detected. Stool analysis for ova and parasites was negative. Subsequent endoscopy with extended depth of field as well as texture and color enhancement imaging (TXI) (Olympus EVIS X1 CV 1500) showed small whitish subepithelial nodules in all segments of the colon, which were especially visible in TXI mode ( Fig. 1; Video 1). In addition, some nodules had a central dark spot which was clearly visible as a protruding nipple on magnified narrow-band imaging (NBI) ( Fig. 2; - Video 1). Histopathological analysis of snare resection specimens showed multiple eosinophilic granulomas with Schistosoma mansoni eggs in the lamina propria [1]. The dark "nipple" seen on endoscopy was interpreted as a granuloma on the verge of bursting and releasing parasite eggs into the intestinal lumen. Endoscopic imaging of egg release of this clarity and detail in intestinal schistosomiasis has not been published before.

A reassessment of the patient's travel history revealed a visit to Lake Victoria in Tanzania about 1 year prior to presentation; having swum in the lake he had been infected with larvae of Schistosoma mansoni. After oral praziquantel treatment his symptoms resolved.

Schistosomiasis is a disease of global concern with about 250 million infections worldwide [2]. It is probably as old as mankind and is described in ancient Egyptian medical papyri [3]. Positive DNA samples have been obtained from Egyptian mummies, and the biblical story of Jericho has been linked to schistosomiasis $[3,4]$. With increased global travel and migration, it is important that physicians in general and endoscopists in particular should become more aware of travel-associated diseases. Modern endoscopic imaging can improve medical un-

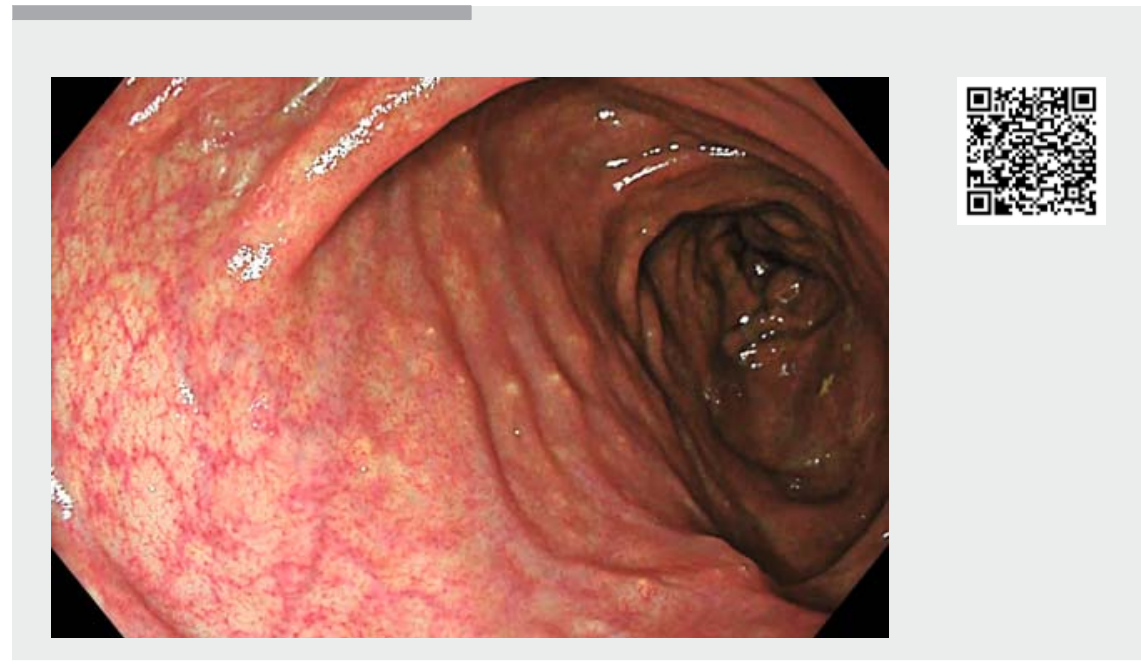

Video 1 Whitish subepithelial nodules containing Schistosoma mansoni eggs in the colon of a 21-year-old male patient. A black nipple can be seen on one of the depicted nodules, suggesting granuloma burst and egg release into the intestinal lumen.

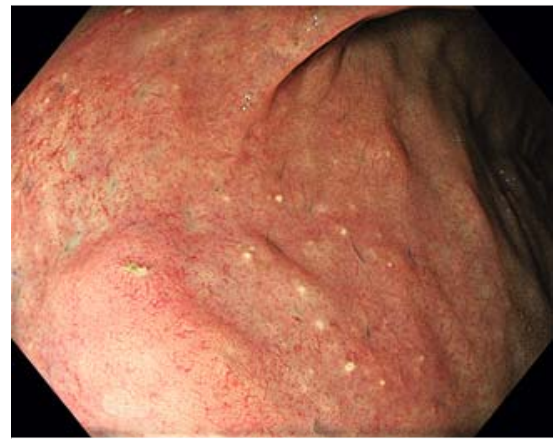

- Fig. 1 Texture and color enhancement imaging of whitish nodules and pseudopolyps in intestinal schistosomiasis; histopathology showed eosinophilic granulomas and Schistosoma mansoni eggs.

derstanding of such diseases, especially those with gastrointestinal manifestations.

Endoscopy_UCTN_Code_CCL_1AD_2AZ

\section{Competing interests}

The authors declare that they have no conflict of interest.

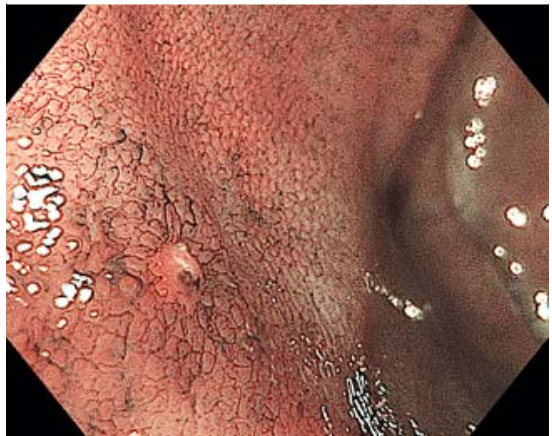

- Fig. 2 Enhanced and magnified endoscopic view (narrow-band imaging) of a whitish nodule with a dark-colored nipple suggestive of granuloma burst and egg release into the colonic lumen. There is obvious hypervascularization around the nodule.

The authors

Alanna Ebigbo, Maria Kahn, Stephan Zellmer, Helmut Messmann

Department of Gastroenterology and Infectious Diseases, University Hospital, Augsburg, Germany 
Corresponding author

\section{Alanna Ebigbo}

Department of Gastroenterology and Infectious Diseases, University Hospital, Augsburg, Stenglinstr. 2, 86156 Augsburg, Germany

Alanna.ebigbo@gmx.de

\section{References}

[1] Llanwarne F, Helmby H. Granuloma formation and tissue pathology in Schistosoma japonicum versus Schistosoma mansoni infections. Parasite Immunol 2020. doi:10.1111/pim. 12778

[2] Tchuem Tchuenté LA, Rollinson D, Stothard JR et al. Moving from control to elimination of schistosomiasis in sub-Saharan Africa: time to change and adapt strategies. Infect Dis Poverty 2017; 6: 42

[3] Di Bella S, Riccardi N, Giacobbe DR et al. History of schistosomiasis (bilharziasis) in humans: from Egyptian medical papyri to molecular biology on mummies. Pathog Glob Health 2018; 112: 268-273

[4] Hulse EV. Joshua's curse and the abandonment of ancient Jericho: schistosomiasis as a possible medical explanation. Med Hist 1971; 15: 376-386

\section{Bibliography}

Endoscopy 2021; 53: E251-E252

DOI 10.1055/a-1252-2637

ISSN 0013-726X

published online 23.9.2020

(c) 2020. Thieme. All rights reserved.

Georg Thieme Verlag KG, Rüdigerstraße 14,

70469 Stuttgart, Germany
ENDOSCOPY E-VIDEOS

https://eref.thieme.de/e-videos

口局 Endoscopy E-Videos is a free access online section, reporting 田: on interesting cases and new techniques in gastroenterological endoscopy. All papers include a high quality video and all contributions are freely accessible online.

This section has its own submission website at https://mc.manuscriptcentral.com/e-videos 